\title{
PERANCANGAN MULTIMEDIA SEBAGAI MEDIA SOSIALISASI SOP KEPADA KARYAWAN PT. TRANSCON INDONESIA
}

\author{
Hutomo Setia Budi \\ (Email: hbudi@ciputra.ac.id) \\ Jurusan Desain Komunikasi Visual \\ Fakultas Industri Kreatif \\ Universitas Ciputra \\ UC Town, Surabaya, Indonesia
}

\begin{abstract}
ABSTRAK
Setiap perusahaan atau organisasi biasanya memiliki suatu prosedur tertentu untuk melakukan suatu kegiatan. Untuk mempermudah mengorganisir kegiatan berulang yang terjadi dalam perusahaan atau organisasi diperlukan suatu standarisasi prosedur kegiatan yang biasa disebut dengan SOP (Standar Operasional Prosedur). SOP kegiatan perlu untuk disosialisasikan kepada pihak-pihak yang terlibat dalam prosedur, sehingga dapat mengerti dan menjalankan prosedur sesuai standar yang berlaku. Menggunakan metode kualitatif dan studi literatur, dengan mengumpulkan informasi dalam teknik wawancara mendalam dari pihak internal PT. Transcon Indonesia. Perancangan Presentasi dengan menggunakan multimedia dalam bentuk penggabungan elemen audio, visual, dan animasi dengan gaya Flat Design dinilai sesuai untuk menyampaikan presentasi SOP yang topikal.
\end{abstract}

Kata Kunci: multimedia; presentasi; SOP

\begin{abstract}
Every firm or organization usually has a specific procedure in performing its activity. To make it easier in organizing events that occur repeatedly within a firm or organization, standardized activities are needed. Standardization procedure in a company is commonly called the SOP (Standard Operating Procedure). The SOP of the activities should be conveyed to all parties involved so that they can understand and execute the procedure according to applicable standards. The research methods used are qualitative method and literature studies conducted by collecting information in in-depth interviews from the internal party of PT. Transcon Indonesia. The presentation is designed in a multimedia form that combines audio, visual, and animation elements with flat design style, considered appropriate to deliver topical SOP presentation.
\end{abstract}

Keywords: multimedia; presentation; SOP 


\section{PENDAHULUAN}

Setiap perusahaan baik besar maupun kecil tentu memiliki suatu cara atau prosedur dalam beroperasi yang biasa disebut dengan SOP (Standard Operational Procedure). SOP dalam perusahaan digunakan untuk memudahkan operasional perusahaan, kejelasan prosedur sistem dalam bekerja agar kinerja perusahaan menjadi lebih baik dan efektif.

SOP adalah suatu aturan yang digunakan untuk mengatur tahapan suatu proses kerja atau prosedur kerja tertentu yang bersifat tetap, rutin, dan tidak berubah-ubah (Budiharjo, 2014). Pada dasarnya, SOP adalah suatu pedoman yang berisi prosedur operasional yang dijadikan standar oleh suatu organisasi atau perusahaan yang berfungsi untuk menjaga agar suatu sistem kerja dapat berjalan efektif dan efisien, konsisten, standar dan sistematis (Tambunan, 2013). SOP dalam suatu perusahaan perlu untuk disampaikan kepada semua pihak yang terlibat dalam sistem kerja perusahaan. Penyampaian SOP yang baik kepada semua pihak yang terlibat akan membuat SOP lebih mudah dimengerti dan dijalankan.

Perubahan sistem dari sistem manual menjadi sistem digital yang dilakukan tentunya mengakibatkan beberapa perubahan yang terjadi dalam prosedur. Perubahan-perubahan yang terjadi dari prosedur lama yang dilakukan secara manual menjadi prosedur baru yang dilakukan secara digital perlu untuk disosialisasikan kepada seluruh pihak internal yang terlibat dalam SOP baru.

Upaya untuk mensosialisasikan perubahan prosedur tersebut membutuhkan sarana komunikasi yang efektif untuk menyampaikan informasi kepada seluruh pihak yang terlibat tentang perubahan prosedur dalam layanan perusahaan. Perancangan ini mengambil studi kasus PT. Transcon Indonesia.

PT. Transcon Indonesia adalah sebuah perusahaan yang berdiri sejak tahun 2007 yang bergerak di bidang logistik. Pada tahun 2016, PT. Transcon Indonesia mulai melakukan perubahan sistem dari sistem manual menjadi sistem digital dengan memanfaatkan teknologi. Oleh karena itu dibutuhkan sebuah sarana pendukung untuk mensosialisasikan perubahan prosedur tersebut pada jajaran karyawannya. 


\section{METODE PENELITIAN}

Dalam perancangan ini, didukung oleh penelitian yang menggunakan metode kualitatif dengan melakukan wawancara mendalam dan didukung oleh studi literatur. Metode kualitatif dipilih dalam penelitian ini karena beberapa keunggulan metode ini, yaitu:

1. Data yang sangat mendasar karena berdasarkan fakta, peristiwa, dan realita.

2. Mengetahui permasalahan secara mendalam.

3. Pembahasan lebih mendalam dan terpusat karena data digali secara mendalam. Hasil penelitiannya unik dan partikular karena bersumber dari tempat tertentu dan tidak mudah untuk disalin dan diterapkan di tempat lain.

4. Terbuka pada lebih dari satu pandangan dari informasi oleh partisipan. Hasil penelitian tidak diasumsikan oleh peneliti di awal penelitian (Raco, 2010).

Penggalian informasi dalam penelitian ini dilakukan dengan menggunakan teknik wawancara mendalam, dengan memilih responden yang berasal dari pihak internal PT. Transcon Indonesia. Pihak internal tersebut adalah jajaran manajemen PT. Transcon Indonesia yang terlibat dalam proses penyampaian SOP baru. Wawancara mendalam terhadap responden dari pihak internal PT. Transcon Indonesia berjumlah empat orang, yaitu direktur, perwakilan divisi IT, perwakilan divisi logistik, dan perwakilan divisi kargo dari PT. Transcon Indonesia.

Fokus pertanyaan yang ditanyakan kepada responden internal PT. Transcon Indonesia adalah sebagai berikut:

1. Sistem kerja dan SOP lama

2. Sistem kerja dan SOP baru

3. Penggunaan teknologi digital seperti apa yang akan diterapkan oleh PT. Transcon Indonesia

4. Kelebihan yang ada dari sistem baru dibandingkan dengan sistem yang lama

5. Kebiasan berkomunikasi dan media yang digunakan dalam komunikasi

6. Kebiasaan pihak yang terlibat dalam SOP baru PT. Transcon Indonesia

7. Tingkat pendidikan dari pihak yang terlibat dalam SOP baru PT. Transcon Indonesia. 


\section{Presentasi sebagai Metode Penyampaian Pesan}

Presentasi dapat diartikan juga sebagai sebuah perlakuan praktis, didorong oleh isi, dan spesifik tentang suatu topik. Presentasi difokuskan pada penyampaian informasi (Bates, 2005:131). Di dalam presentasi sendiri terdapat berbagai macam metode untuk menyampaikan pesan. Ditinjau dari organisasi pesan, dalam presentasi terdapat lima macam jenis presentasi, yaitu: deduktif, induktif, kronologis, spasial, dan topikal. Dalam metode deduktif, presentasi dimulai dengan menyatakan dulu gagasan utama, kemudian memperjelasnya dengan keterangan penunjang, penyimpulan dan bukti. Sebaliknya, dalam urutan induktif presentasi dimulai dengan mengemukakan perincian-perincian dan kemudian menarik kesimpulan. Dalam urutan kronologis, pesan disusun berdasarkan urutan waktu terjadinya peristiwa. Urutan logis, pesan disusun berdasarkan sebab-ke-akibat atau akibat-ke-sebab. Dalam urutan spasial, pesan disusun berdasarkan tempat. Urutan topikal, pesan disusun berdasarkan topik pembicaraan. Menurut Rakhmat untuk presentasi tentang penyampaian SOP, metode yang cocok untuk digunakan adalah jenis presentasi topikal dimana presentasi disusun berdasarkan topik pembicaraan (Rakhmat, 2008: 41-43).

Seiring perkembangan teknologi digital, presentasi dengan menggunakan media digital pun makin sering digunakan. Media digital yang melibatkan audio dan visual banyak digunakan sebagai alat bantu dalam presentasi untuk menyampaikan pesan. Audio visual yang digunakan dalam presentasi diharapkan mampu membantu penyampaian pesan dengan baik dan jelas kepada audience, sehingga audience dapat lebih mudah mengerti dan memahami maksud yang hendak disampaikan.

\section{Multimedia sebagai Sarana Presentasi}

Salah satu metode untuk membantu presentasi adalah dengan memanfaatkan bantuan gambar (visual), dikarenakan manusia lebih mudah belajar dari kata/kalimat dan gambar dibandingkan dari kata/kalimat saja, (Mayer, 2014). Selain gambar, presentasi juga dapat didukung dengan suara (audio) dan tulisan (teks) untuk lebih memperjelas maksud dan makna yang hendak disampaikan. Media yang mampu untuk menggabungkan elemen-elemen tersebut adalah melalui Multimedia. Multimedia secara umum dapat diartikan sebagai penggabungan berbagai infomasi dengan menggunakan fasilitas dari komputer. Multimedia yang berasal dari kata multi yang berarti banyak atau lebih dari satu dan media yang dapat diartikan penyajian suatu 
tempat. Multimedia adalah pemanfaatan komputer untuk membuat dan menggabungkan teks, audio, gambar, bergerak (video dan animasi dengan menggunakan link dan tool yang memungkinkan pemakaian melakukan navigasi, berinteraksi, berkreasi dan berkomunikasi (Suyanto, 2004).

Multimedia bertujuan untuk menyajikan informasi dalam bentuk yang menyenangkan, menarik, mudah dimengerti, dan jelas, (Arsyad, 2009: 169-171). Multimedia dapat menjadi alat bantu yang menyenangkan karena kekayaan elemen dan kemudahan penggunaan dalam banyak konten yang bervariasi. Pemanfaatan multimedia dalam bisnis meliputi presentasi, pemasaran, periklanan, demo produk, katalog, komunikasi di jaringan, dan pelatihan, (Binanto, 2010: 4). Dari hasil studi literatur tentang komunikasi didapatkan hasil multimedia merupakan salah satu media yang efektif untuk mendukung dalam menyampaikan pesan berkaitan dengan pembelajaran dan penyampaian suatu informasi.

\section{Flat design}

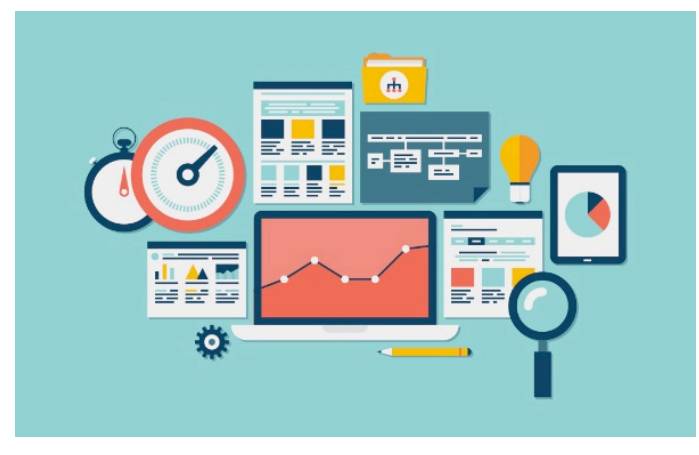

Gambar 1. Flat design

Sumber: http://alterimaging.com/blog/wp-content/uploads/flat_design.jpg

Flat Design adalah gaya desain dua dimensi. Inti dari gaya desain ini adalah tidak ada elemen yang membuat desain memiliki efek tiga dimensi seperti bayangan, perspektif, tekstur, gradasi, dan sebagainya. Gaya desain ini memiliki karakteristik sebagai berikut:

1. Simplifikasi dari efek visual yang memberikan hasil desain tampak bersih, akurat, dan efisien sehingga penekanan dan pesan lebih mudah tersampaikan.

2. Berfokus pada konten. 
3. Kemudahan dalam pengaplikasian dalam hubungannya dengan teknologi digital pendukung dan resolusi digital dimana gaya desain ini akan tetap tampak bagus dalam resolusi dan ukuran media digital yang bervariasi.

Dalam flat design penggunaan animasi membuat efek yang positif karena gerakan-gerakan yang tidak berlebihan menghindarkan kesan monoton yang membosankan (Cheng-lin; Jianwei, 2016).

Berikut adalah contoh dari gaya Flat Design:

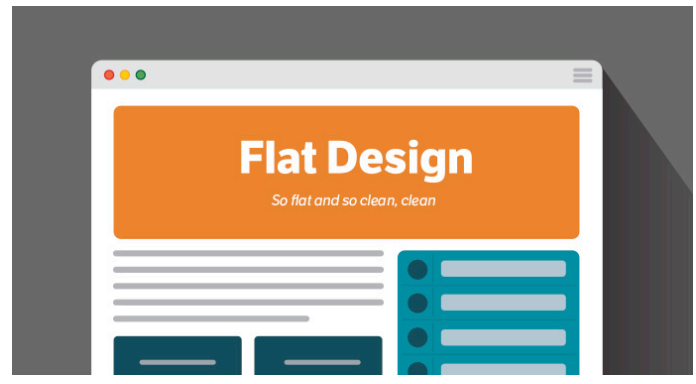

Gambar 2. Flat design

Sumber: https://think360studio.com/wp-content/uploads/2016/03/flat-design.jpg

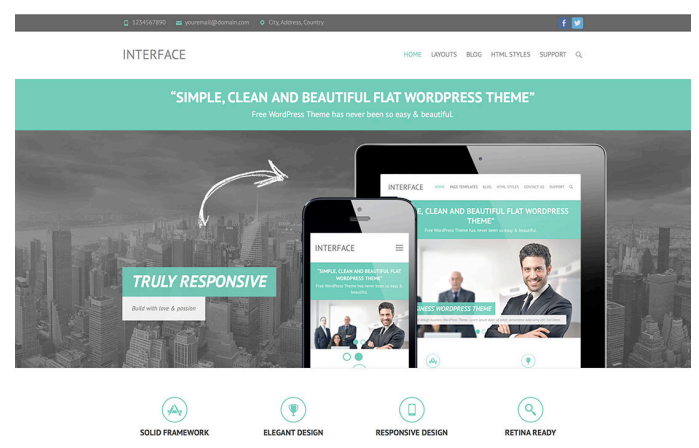

Gambar 3. Flat design dengan fotografi

Sumber: https://cdn.colorlib.com/wp/wp-content/uploads/sites/2/free-flat-design-themes.jpg

\section{PEMBAHASAN}

Berdasarkan data wawancara mendalam yang didapat, didukung dengan referensi dari literatur. upaya untuk mengkomunikasikan SOP baru kepada pihak internal PT. Transcon Indonesia menggunakan multimedia sebagai pendukung presentasi yang mengandung elemen audio, 
visual, dan animasi. Multimedia akan membantu presenter memperjelas isi pesan yang hendak disampaikan kepada audience.

\section{Tahap Pertama:}

\section{Perancangan Tahapan Desain Multimedia}

Materi multimedia dalam bentuk audio, visual dan animasi, berupa data yang telah dikumpulkan terlebih dahulu, kemudian dirangkum dan dibuat garis besarnya. Setelah itu dimulailah proses produksi dari pembuatan naskah, storyboard, editing audio visual. Berikut adalah bagan proses perancangan tahapan desain multimedia.

\section{Tahap Kedua:}

\section{Perancangan Konsep Kreatif Dalam Presentasi SOP PT. Tascon Indonesia}

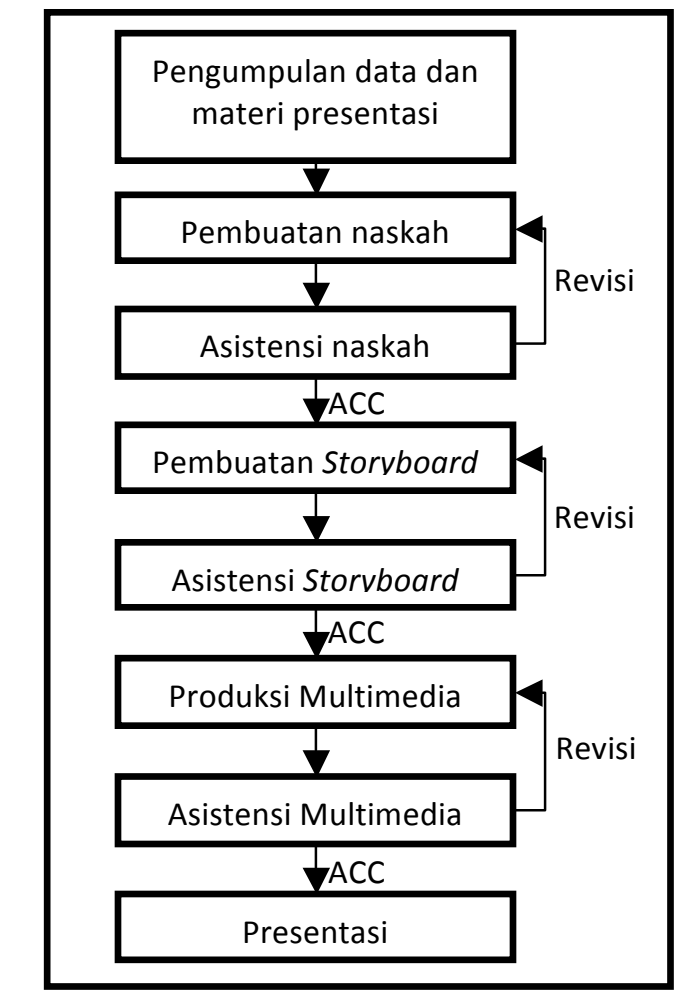

Gambar 4. Proses perancangan tahapan desain multimedia Sumber: Penulis, 2017

Gaya desain yang digunakan dalam perancangan multimedia presentasi ini adalah menggunakan gaya flat design yang dipadukan dengan animasi. Flat design dipilih karena memiliki karakteristik desain yang bersih, akurat, berfokus pada konten, dan mudah untuk 
diaplikasikan pada berbagai media. Penggunaan elemen animasi dalam multimedia mengakibatkan presentasi menjadi tidak monoton dan lebih menarik.

Warna yang digunakan dalam perancangan ini didominasi oleh warna merah, biru, dan abuabu. Warna merah yang digunakan dalam perancangan ini menandakan penekanan pada informasi yang akan disampaikan. Warna merah digunakan karena selain penekanan tersebut juga merupakan salah satu elemen warna yang terdapat dalam logo perusahaan PT. Transcon Indonesia.

Warna biru diterapkan dalam tampilan presentasi adalah warna korporat dari PT. Transcon Indonesia yaitu warna biru. Warna biru digunakan karena menggambarkan stabilitas, kepercayaan, dan memiliki efek psikologi menenangkan. Warna abu-abu digunakan karena memberikan nuansa yang netral, sebagai background untuk mendukung komposisi dan memberikan efek kontras yang jelas. Pada ilustrasi karakter juga menggunakan warna cerah untuk mendapatkan kesan menyenangkan dan tidak kaku sehingga audience tidak tegang, tidak bosan dan santai ketika melihat presentasi SOP tersebut sehingga pesan dapat disampaikan dengan lebih fokus dan baik. Berikut adalah kode warna RGB dari warna merah, biru, dan abu-abu dalam perancangan ini.

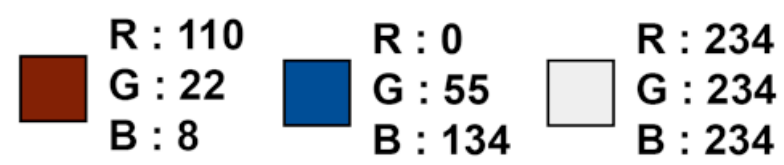

Gambar 5. Kode warna RGB dalam layout perancangan Sumber: Penulis, 2017

Tipografi yang digunakan jenis font san-serif. Font san-serif dipilih karena jenis font ini lebih mudah dibaca, dan memiliki kesan yang kokoh dan profesional. Keterbacaan teks dalam perancangan ini sangat penting karena tujuan utama dalam perancangan ini adalah untuk menyampaikan pesan. Pada Teks menggunakan type family dari huruf yang dipilih serta pengaturan ukuran huruf. Hal tersebut digunakan untuk memberi penekanan pada hirarki baca yang hendak disampaikan. Bagian yang lebih penting menggunakan type family Bold dengan ukuran yang lebih besar, sedangkan bagian selanjutnya menggunakan type family regular dengan ukuran huruf yang lebih kecil. 


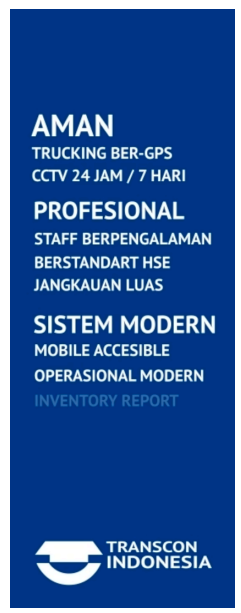

Pengecekan

Berkas - berkas kargo masuk \& keluar

Gambar 6. Aplikasi warna dalam perancangan

Sumber: Penulis, 2017

Font yang digunakan dalam perancangan ini adalah font Gotham dengan tipe bold dan reguler. Berikut adalah gambar font Gotham.

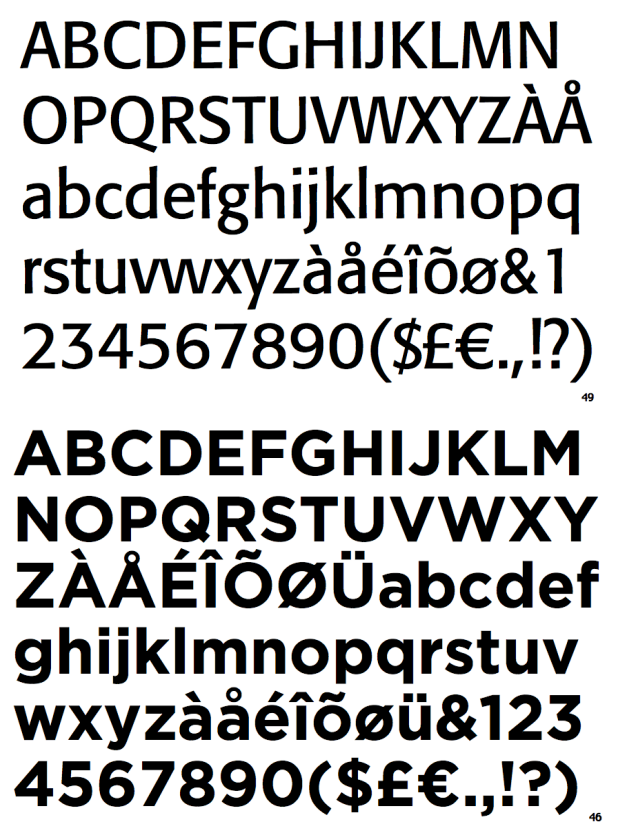

Gambar 7. Gotham Regular dan Bold Sumber: Google Image, 2017

Dalam perancangan ini, ditampilkan ilustrasi karakter dari karyawan PT Transcon Indonesia dari divisi yang terlibat dalam proses. Gaya ilustrasi yang digunakan dalam perancangan ini adalah gaya gambar dengan teknik vektor. Berikut adalah ilustrasi karakter dari staff PT Transcon Indonesia yang digunakan dalam perancangan. 


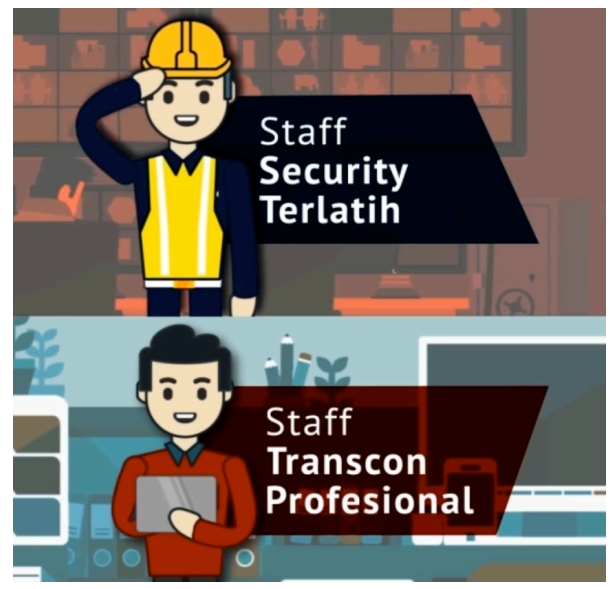

Gambar 8. Ilustrasi karakter staff dengan gaya vector dengan Flat Design Sumber: Penulis, 2017

Desain dalam perancanggan ini menggunakan layout dengan sistem dengan Grid. Grid digunakan untuk memberikan kesan rapid an professional. Pada bagian kiri terdapat persegi panjang yang dimunculkan secara berulang untuk menjaga konsistensi layout terlihat rapi, professional, sekaligus sebagai sarana untuk menunjukkan keunggulan PT. Transcon Indonesia.

Berikut adalah visualisasi hasil perancangan:

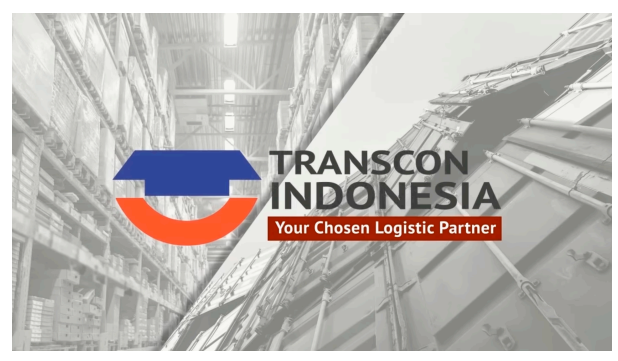

Gambar 9. Tampilan pembukaan dengan gabungan logo perusahaan dengan fotografi Sumber: Penulis, 2017

Gambar 10. Penggunaan teks dan warna untuk menekankan pesan dalam perancangan Sumber: Penulis, 2017 


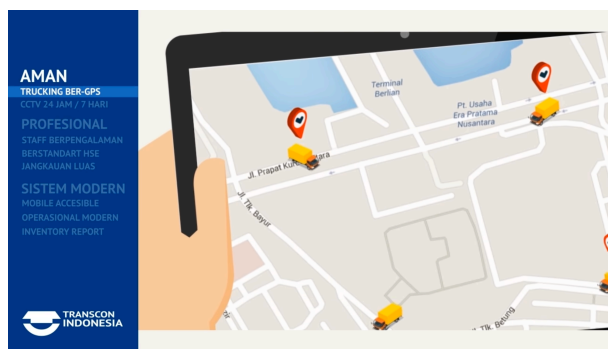

Gambar 11. Penggunaan animasi untuk menjelaskan status dan lokasi barang Sumber: Penulis, 2017

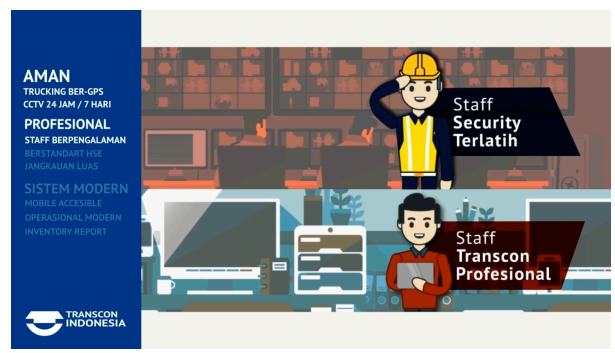

Gambar 12. Aplikasi Flat Design dalam perancangan Sumber: Penulis, 2017

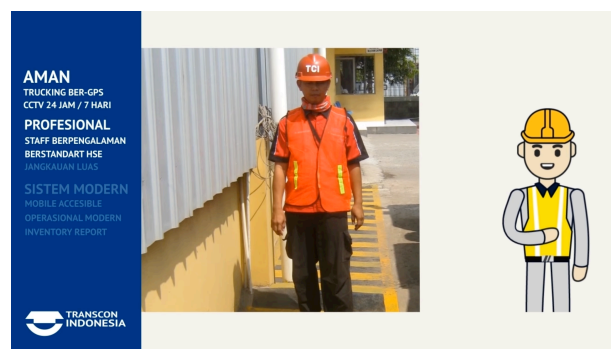

Gambar 13. Penggabungan karakter ilustrasi staf vektor dengan foto untuk dalam perancangan untuk penekanan informasi

Sumber: Penulis, 2017

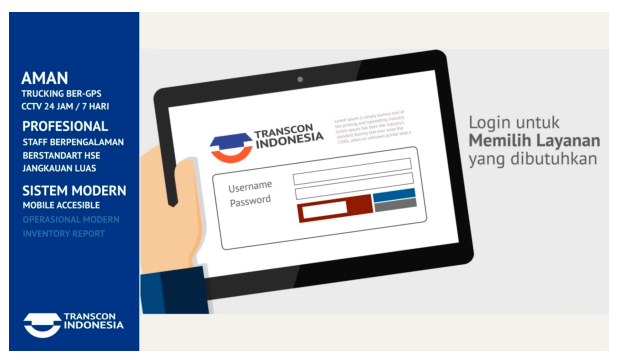

Gambar 14. Penggunaan animasi prosedur login untuk user Sumber: Penulis, 2017 
Serat Rupa Journal of Design, May 2017, Vol.1, No.3: 461-474

Hutomo Setia. B - Perancangan Multimedia Sebagai Media Sosialisasi SOP Kepada Karyawan PT. Transcon Indonesia.

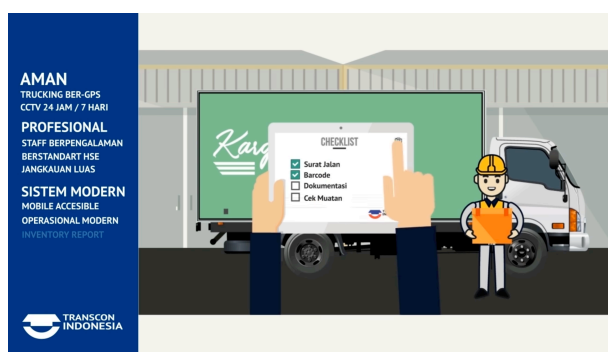

Gambar 15. Penggunaan animasi SOP pemasukan barang ke gudang

Sumber: Penulis, 2017

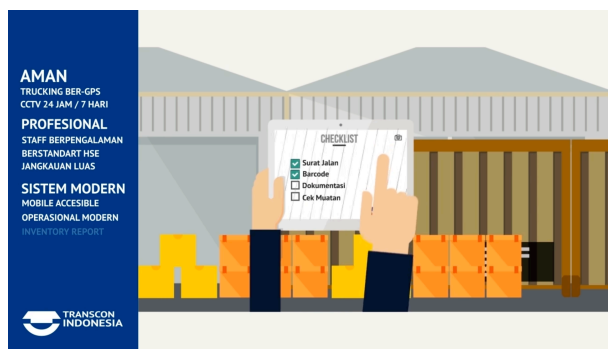

Gambar 16. Penggunaan animasi dengan flat design untuk menjelaskan SOP perusahaan Sumber: Penulis, 2017

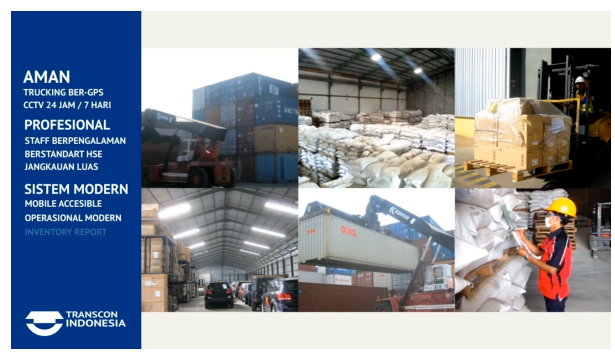

Gambar 17. Penggunaan fotografi sebagai pendukung dan penguat pesan tentang fasilitas yang telah ada dalam PT Transcon Indonesia Sumber: Penulis, 2017

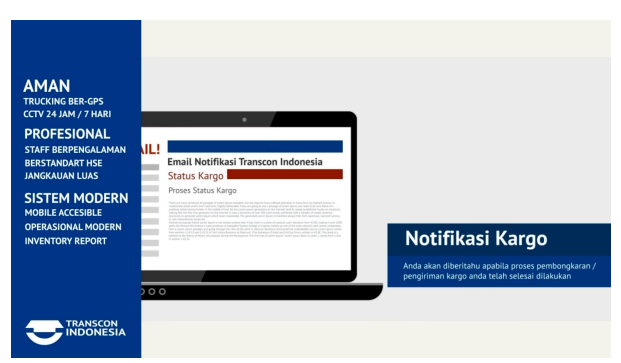

Gambar 18. Penggunaan animasi untuk menjelaskan prosedur login pelanggan baru Sumber: Penulis, 2017 


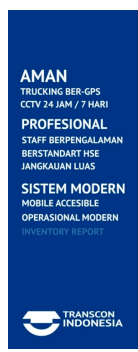

Gambar 19. Penggunaan animasi dengan flat design untuk menjelaskan prosedur sistem dalam perusahaan Sumber: Penulis, 2017

\section{PENUTUP}

Setelah disosialisasikannya SOP baru, berdasarkan evaluasi yang dilakukan paska perancangan desain. Jajaran karyawan PT. Transcon Indonesia dapat memahami SOP prosedur baru yang disampaikan, dengan jelas. Hal tersebut mengungkapkan bahwa penggunaan multimedia dalam bentuk penggabungan elemen audio, visual, dan animasi dengan gaya Flat Design sesuai untuk menyampaikan presentasi SOP yang topikal atau isinya disusun berdasarkan topik pembicaraan.

\section{DAFTAR PUSTAKA}

Arsyad, Azhar. (2009). Media Pembelajaran. Jakarta: PT. Raja Grafindo Persada.

Bates, Suzanne. (2005). Speak Like a CEO: Kuasai Keahlian Bicara Seorang CEO. Jakarta: Bhuana Ilmu Populer.

Binanto, Iwan. (2010). Multimedia Digital, Dasar Teori + Pengembangannya. Yogyakarta: CV. Andi Offset.

Budihardjo, Muhammad. (2014). Panduan Praktis Menyusun Sop (Standard Operating Procedure). Yogyakarta: Penerbit Swadaya.

Effendy, Onong Uchjana. (2009). Ilmu Komunikasi, Teori \& Praktek. Bandung: PT. Remaja Rosdakarya.

Mayer, Richard E. (2014). The Cambridge Handbook of Multimedia Learning. Santa Barbara: University of California Press.

M. Suyanto. (2004). Aplikasi Desain Grafis Untuk Periklanan. Yogyakarta: CV. Andi Offset. 
Raco, J. R. (2010). Metode Penelitian Kualitatif, Jenis, Karakteristik, dan Keunggulannya. Jakarta: Grasindo - PT. Gramedia Widiasarana Indonesia.

Rakhmat, Jalaluddin.(2008). Retorika Modern: Pendekatan Praktis. Bandung: PT. Remaja Rosdakarya.

Tambunan, Rudi M. (2003). Pedoman Penyusunan Standart Operating Prosedures (SOP). Jakarta: Maistas Publishing.

\section{Sumber Online}

Huan, Cheng-lin; Chen, Jian-wei. (2015). Flat Design Study of Power Point Teaching Presentation, Diunduh06 Januari 2017 dari http://www.scipublish.com/journals/EPI/papers/download/11 load/1101-1441.pdf 